\title{
Indonesian-English Code Mixing in Raditya Dika's Manusia Setengah Salmon
}

\author{
Santika Wulandari \\ chantuet@gmail.com \\ SMA Asseruyaniyyah Seruyan \\ Jl. Letjen S. Parman Persil Raya, Seruyan Hilir, Kalimantan Tengah, Indonesia
}

Received: January 22, 2016; Accepted: March 3, 2016; Published: March 25, 2016

\begin{abstract}
This study was aimed at investigating Indonesian-English code mixing in Raditya Dika's Manusia Setengah Salmon, particularly to find out the word classes of the code mixing, the meaning of the code mixing, the dominant use of the code mixing, and the reasons for using the code mixing. Content analysis in qualitative approach was applied in this study. To collect the data, it was through data collection, data reduction, data display, and conclusion drawing. The results showed that there are 65 sentences or utterances consisted English nouns as code mixing. They were categorized into countable nouns $(87.69 \%)$, uncountable nouns $(3.08 \%)$, abstract nouns $(6.15 \%)$, concrete nouns $(1.54 \%)$, and plural nouns $(1.54 \%)$. Among them, countable nouns are more dominant than others. Also, three kinds of translating process found are: borrowing consisted of 25 sentences, literal consisted of 14 sentences, and adaptation consisted of 28 sentences.
\end{abstract}

Keywords: Indonesian-English code mixing, word class, meaning, content analysis, Manusia Setengah Salmon

How to cite this paper: Wulandari, S. (2016). Indonesian-English Code Mixing in Raditya Dika's Manusia Setengah Salmon. Journal on English as a Foreign Language, 6(1), 71-82. 
Language can be used to convey opinion, idea, and feeling, although the fiction or imagination situation. It is the imagination situation like literature (poetry, story, fairy tale, legend, and joke) that used for speaker's happiness or the reader (Chaer \& Agustina, 2010, p. 17). To communicate with others they need language as a tool of communication. Communication is a process by which information is exchanged between individuals through a common system symbols, signs, or behavior. In today's modern world, globalization is the main factors considered in everybody life. It plays an important role in the development some factor.

During the processes of interpersonal communication, the problems of high importance are solved or discussed. The success of intercultural communication depends on the development of intercultural competence of intelligence, on how people negotiate, meet, greet and relationship worldwide (Kolosova, 2011, p. 14). The study of language in relation to the society is called sociolinguistics. Sociolinguistics is the study of the language function in a social context and the development of language in society. Sociolinguistics focuses on differences in the use of language in society so that an object can be the object language learning another language. Then, the question of language is the fundamental question of power. From the statement, it is clear that sociolinguistics is the study of language use in a society that did not focus on the composition of sentence structure but focuses on differences in language use and language development in society (Wardhaugh, 2006, p. 1).

People speak based on where they came from and their environment. When people are in conversation they use the language that they have, generally people often use more than one language. It is very common that people develop some knowledge and ability in a second language and so become bilingual. The simplest definition of a bilingual is a person who has some functional ability in a second language. This may vary from a limited ability in one or more domains, to very strong command of both languages (Alam, 2006, p. 54) there are many more bilingual or multilingual individuals in the world than there are monolingual. Monolingual refers to the ability to use only one language. Bilingual is an ability to use two language and multilingual for more than two languages (Saville \& Troike, 2006, p. 8).

Nowadays, many Indonesian people use Indonesian and English at the same time. This condition is called code mixing because the condition where people use more than one language on the same topic. Code mixing is the use more than language that speakers or writers mix two codes or more language in discourse; the main characteristics in code mixing are relaxed situations and informal situation (Saputro, 2013, p. 3). Many factors which influenced the people mix the code, such as their background as like education, culture, social, 
economic, etcetera. Education is one of the parts of background the people mix the code if the people have a good education so it influenced their mix code. In written language code mixing presented in italic or underlined style at word or phrase. In this research, it was discussed one novel entitled Manusia Setengah Salmon written by Raditya Dika. He is the author or novelist who used code mixing in his novel. He is the first Indonesian bloggers who managed to make a book from his blog. He has known as the author of the humorous book. He has written some novels like Kambing Jantan, Cinta Brontosaurus, Radikus Makankakus, Babi Ngesot, Marmut Merah Jambu and Manusia Setengah Salmon, and Koala Kumal.

Manusia Setengah Salmon is the sixth novel written by Raditya Dika which was published in 2011. It was published by Gagas Media in Jakarta Selatan. The story still has concept comedy based on stories written by the author as in the previous book. This book contains 258 pages and 19 chapters. Manusia Setengah Salmon novel made worth reading among teenagers and adults.

This novel is one of the non-fictions comedies. The sixth Raditya Dika's novel, he adds pieces of the story from his previous novels that relate this novel. Manusia Setengah Salmon novel focuses on the intrinsic elements because the content of the story is very good and more interesting than intrinsic elements.

The language used is daily language. So, if the readers read the novel, they can instantly understand the words that are delivered by the author. Then in this novel, the author provides symbols or emoticons for the readers.

This novel contains nineteen chapters that tell a lot about the displacement Raditya Dika. The start of moving house, moving family relationships, moving the driver and moved hearts.

As an illustration, the writer presented a little bit sentence which describes the reality of language used in which afterward the reality of language use can be categorized as code mixing. The sentence is as follows: Gue jadi jarang bisa ngelakuin kegiatan seperti maen game atau bahkan sekedar lari sore bersama (Dika, 2011, p. 13).

The sentence above indicates the existence of code mixing because the speaker used one word or phrase of English into Indonesia language. The speakers master both languages they used it to express their emotion, feeling or thought. It is found that there are variation forms and type code mixing used.

Based on phenomenon above, the writer wants to investigate the style of code mixing in Raditya Dika's Manusia Setengah Salmon. The study focused on determining the forms of words in the process of word-formation, the meaning, the dominant code mixing words, and the reasons for using code mixing. 
Therefore, it is a very interesting investigation on the novel. Based on the background of the study, the research problem are:

1) What are the word classes of Indonesian-English code mixing used in Raditya Dika's Manusia Setengah Salmon?

2) What are the meanings of code mixing found in Raditya Dika's Manusia Setengah Salmon?

3) What are the dominant Indonesian-English code mixing used in Raditya Dika's Manusia Setengah Salmon?

4) Why is code mixing used in Raditya Dika's Manusia Setengah Salmon?

The current study follows the way of doing the research by some researchers. Dalimunthe (2011) reported from her study about code mixing. It was found code mixing in Girlfriend Magazine. The result of the study showed that the code mixing is dominantly used in Girlfriend Magazine found 45, 58\% words, $42,02 \%$ phrase, and $11,99 \%$ clause. Also, a study was conducted by Saputro (2013) in which his study subject is in Marmut Merah Jambu novel. It is found that there are several reasons why the writer in the novel uses Indonesian-English code mixing. He showed that there are some forms that use, such as words, phrase, hybrid, clause, and idiom.

The study could hopefully give benefits: It gave readers additional information and knowledge of words class, the meaning, the dominant code mixing words, and the reasons for using code mixing in Raditya Dika's Manusia Setengah Salmon, and it is also expected to inform the English students so that they got many words to increase their vocabulary and to improve their English skills.

\section{METHOD}

It was used qualitative method approach in this research with document or content analysis as research type. Content analysis focused and interpreted textbooks material to learn about human behavior. Content or document analysis method applied to written or visual materials for the purpose of identifying specified characteristics of the material. The material analyzed can be texts, newspapers, or any type of documents.

According to Gao $(1989$, p. 6), content analysis is a set of the procedures for collecting and organizing information in a standardized format that allows analysts to make inferences about the characteristics and meaning of written and other recorded material. Simple formats can be developed for summarizing information or counting the frequency of statements. It is in line with Berelson's opinion cited by Gao (1989), content analysis is a research technique for the objective, systematic, and qualitative description of the manifest. The content 
analysis confirmed to three basic principles of scientific method. They are objectivity, systematic, and generalizability.

Content Analysis begins with a specific statement of the objectives or research questions to be studied. The researcher must, therefore, locate a source of communication relevant to the research question and ask questions that can be solved by content analysis. It is also known as a method of analyzing documents. The content analysis allows the researcher to test theoretical issues to enhance understanding of the data. Through content analysis, it is possible to distil words into fewer content-related categories. It is assumed that when classified into the same categories the like share the same meaning (Elo \& Kyngas, 2007, p. 107).

Technically, the content analysis applied includes: first, classify efforts signs which use in communication, the writer classified the Indonesia-English code mixing in word classes in Raditya Dika's Manusia Setengah Salmon; second, use criteria as a basis for classification, the writer used the criteria of codemixing based on the theory; third, after knowing the code mixing forms, the writer gave the meaning of words found from dictionaries and matches it based on the story; fourth, the writer shows the dominant code mixing used in Raditya Dika's Manusia Setengah Salmon; finally, use some analysis techniques in making predictions, the writer used some techniques to analysis the forms, meanings dominants and reason of using Indonesia-English code mixing in Raditya Dika's Manusia Setengah Salmon (Muhadjir, 2000, p. 68)

The Table 1 and 2 present some pre-data of code mixing used in Raditya Dika's Manusia Setengah Salmon.

Table 1. First Reader

\begin{tabular}{clccc}
\hline No. & \multicolumn{1}{c}{ Word } & Page & Function & Rotation \\
\hline 1 & Absurd & 2 & Adjective & 1 \\
\hline 2 & Headstand & 3 & Noun & 1 \\
\hline 3 & Cereal & 4 & Noun & 1 \\
\hline 4 & Game & 13 & Noun & 1 \\
\hline 5 & Follower & $15,150,188$ & Noun & 4 \\
\hline
\end{tabular}

The source of the data was taken from the Raditya Dika's novel entitled Manusia Setengah Salmon. The writer chooses this novel because this is one of the best seller novels in Indonesia. This novel concept comedy was written by the author of the story as in previous books. The contents of this novel are very interesting, light reading, funny and also there are many words that can truly inspire. It contains Indonesia-English code mixing in form of words. The data analyzed are the code mixing words that are written by the author in the novel. 
Table 2. Second Reader

\begin{tabular}{|c|c|c|c|c|}
\hline No. & Word & Page & Function & Rotation \\
\hline 1 & Cafe & 22,238 & Noun & 3 \\
\hline 2 & Cool & 22 & Noun & 2 \\
\hline 3 & Well & 26 & Adjective & 1 \\
\hline 4 & Jump & 26 & Noun & 1 \\
\hline 5 & Surprise & 31 & Noun & 1 \\
\hline
\end{tabular}

To collect the data, it was through these steps as follows: (1) The writer read the Novel entitled Manusia Setengah Salmon. (2) The writer selected the Indonesian-English code mixing used in this Novel. (3) The writer wrote and collect the data from the novel. (4) The writer listed the data. (5) The writer classified the data based on the insertion of words. (6) The writer determined the meaning of code mixing that used in the Novel. (7) The writer classified the dominant code mixing words that used in the Novel. (8) The writer analyzed the reason of using code mixing as follow: need feeling native, prestige feeling native, asserting status, pride, and power, being more informative, making jokes, expressing self-emotion.

The data collected in this study is suitable in reality. It is to keep the data collected are true data and responsible. The validity of the data is the conditions that fulfill: Explaining the right value, presenting a base that is applied, permitting another opinion that made consistency (Moleong, 2014, p. 320-321).

In acquiring the data, as suggested by Gunawan (2013, p. 288-289) it was used triangulation. The triangulation used is theory triangulation which involves consideration of how the phenomenon under study might be explained by multiple theories. There are four techniques to determine the validity of data, namely credibility, transferability, dependability and conformability (Sugiono, 2010, p. 366).

\section{FINDINGS}

\section{The Word Classes of Indonesian-English Code Mixing Used in Raditya Dika's Manusia Setengah Salmon}

It was classified into five kinds of nouns that found in IndonesianEnglish code mixing used in Raditya Dika's Manusia Setengah Salmon. Based on the data finding, the writer found 65 sentences or utterances consist of English nouns as code mixing. There were 56 sentences used countable nouns, 3 sentences used uncountable nouns, 1 sentence used a plural noun, 4 sentences used abstract nouns, and 1 sentence used a concrete noun. Furthermore, the writer found $87.69 \%$ of countable nouns, $3.08 \%$ of uncountable nouns, $6.15 \%$ of abstract nouns, $1.54 \%$ of concrete nouns and $1.54 \%$ of plural nouns. According 
to the result of the study showed that countable nouns used more dominant than others.

\section{The Meanings of Code Mixing Found and Dominantly Used in Raditya Dika's Manusia Setengah Salmon}

From the analysis, it shows that the meaning of code mixing used in Raditya Dika's Manusia Setengah Salmon is focused on two kinds of meanings category. They are lexical meaning and contextual meaning. Lexical meaning is a meaning that is explained and described in dictionary. In this study, it was writer used oxford dictionary to find out the meaning of code mixing words. Contextual meaning is the meaning which is determined by its relationship with the other words in a sentence. Sometimes, one word has several dissimilar meaning when it is used in different contexts.

Furthermore, it also shows that the meaning of code mixing words based on the process of translating. It concerned with the technical devices in a deep structure which consist of translation, transliteration, transposition, literal, borrowing, modulation, and adaptation. The kinds of translating process of Indonesian-English code mixing used in Raditya Dika's Manusia Setengah Salmon are as shown in Figure 1.

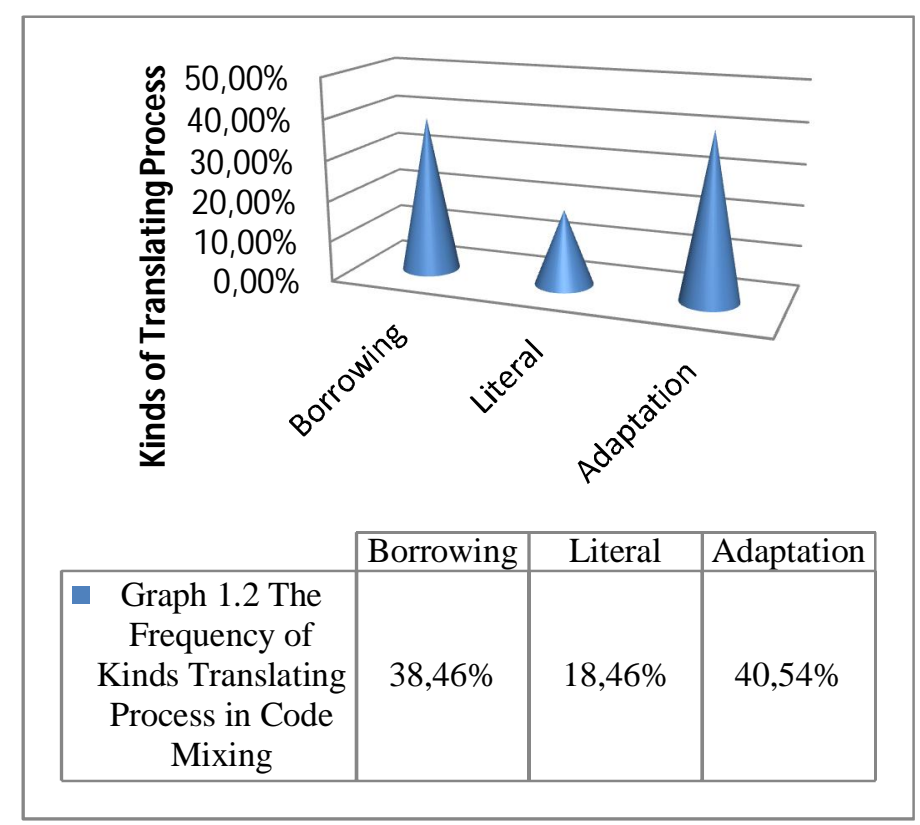

Figure 1. The Frequency of Kinds Translating Process in Code Mixing

Based on Figure 1, the translating process frequency in IndonesianEnglish code mixing used in Raditya Dika's Manusia Setengah Salmon showing high to low level are literal $(18.46 \%)$, borrowing $(38.46 \%)$, and adaptation

Journal on English as a Foreign Language, 6(1), 71-82

Copyright @ 2016 by JEFL, p-ISSN 2088-1657; e-ISSN 2502-6615 
(40.54\%). It is found that there were 25 sentences used borrowing process, 12 sentences used literal process, and 28 sentences used adaptation. Here is that the adaptation process is more dominantly used.

\section{Reasons Why Code Mixing Used in Raditya Dika's Manusia Setengah Salmon}

Based on the theory, it is explained about six purposes why people using code mixing, they divided into need feeling motive, prestige feeling motive, asserting status, pride, and power, being more information, making jokes and expressing self-emotion. It is writer displayed in Table 3.

Table 3. The Percentage of the Purpose Using Code Mixing

\begin{tabular}{clcc}
\hline No & \multicolumn{1}{c}{ The Purpose Using Code Mixing } & Frequency & $\begin{array}{c}\text { Percentage } \\
(\%)\end{array}$ \\
\hline 1 & Need feeling motive & 23 & 35.39 \\
\hline 2 & Prestige feeling motive & 5 & 7.69 \\
\hline 3 & Asserting status, pride and power & 13 & 20.00 \\
\hline 4 & Being more informative & 13 & 20.00 \\
\hline 5 & Making jokes & 9 & 13.85 \\
\hline 6 & Expressing self-emotion & 2 & 3.08 \\
\hline & Total & 65 & 100 \\
\hline
\end{tabular}

Based on Table 3, the most frequency of purpose using code mixing used in Raditya Dika Novel entitled Manusia Setengah Salmon is need feeling motive. The frequency using needed feeling motive 23 sentences or utterance with the percentage of $35.39 \%$. It occurred because when the speaker cannot find words that have a similar meaning in the language they speak, so the speaker often mixed their language into another language. The speakers hope that the interlocutor can understand the message that conveyed.

\section{DISCUSSION}

Based on the data findings and analysis of Indonesian-English code mixing words in Raditya Dika's Manusia Setengah Salmon, it was found that there were 65 sentences that used English nouns. In this part, it is only focused on the form of code mixing (insertion of words), especially nouns. Based on the result, it was found that English nouns are more dominant than other words. Code mixing in Raditya Dika's Manusia Setengah Salmon is the existence of English words together with Indonesian words which are equivalent in meaning. The language used in Raditya Dika's Manusia Setengah Salmon is informal language, so it allows existing in the sentences.

The findings also showed that there were 65 sentences or utterances consisted English nouns as code mixing divided into countable nouns (87.69\%), 
uncountable nouns $(3.08 \%)$, abstract nouns $(6.15 \%)$, concrete nouns $(1.54 \%)$, and plural nouns $(1.54 \%)$. Based on the result, it shows that the countable nouns used were more dominant than others. In this case, mostly English countable nouns cannot be translated into Indonesian used without changing their original words.

According to Suwito cited by Mediyanthi (2012), the forms of code mixing have six classifications, they are, insertion of words, insertion of phrase, insertion of clauses, insertion of idioms, insertion of hybrid and insertion of word reduplication. However, in this study, it only focused on one form that is used more dominant than other forms. It is also found the meaning of all code mixing words. In this study, it is used lexical meaning and contextual meaning. The meaning presented by oxford dictionary and appropriate with the context of the sentence used in Raditya Dika's Manusia Setengah Salmon.

Additionally, based on the findings, it was found three kinds of translating process, they are, borrowing, literal, and adaptation. According to Metham and Hudson cited by As-Safi' (n.d), there were seven technical devices in deep structure. However, the finding of this study shows that only three kinds, they are, borrowing, literal, and adaptation. Meanwhile, the kinds of the translation process in technical devices in a deep structure such as translation, transliteration, transposition, modulation, were not found.

Finally, the purposes of using code mixing used in Raditya Dika's Manusia Setengah Salmon were analyzed. It refers to the theory available in Budianto and Fardhani (2010). The findings show that the code mixing was mostly used as need feeling motive. The frequency using needed feeling motive 23 sentences or utterance with the percentage of $35.385 \%$. It occurred because the speaker cannot find words that have a similar meaning in the language they speak, so the speaker often mixed their language into another language. The speaker hopes that the interlocutor can understand the message that conveyed.

\section{CONCLUSION}

The study focuses on investigating Indonesian-English code mixing used in Raditya Dika's Manusia Setengah Salmon. It was found that the words classes of Indonesian-English code mixing words in the novel were 65 sentences that used English nouns. In this part, it is only focused on the form of code mixing (insertion of words), especially nouns. It also shows that there were 65 sentences or utterances consisted English nouns as code mixing divided into countable nouns $(87.69 \%)$, uncountable nouns $(3.08 \%)$, abstract nouns $(6.15 \%)$, concrete nouns $(1.54 \%)$, and plural nouns $(1.54 \%)$. However, the countable nouns used were more dominant than others. Also, it was found the meaning of all code mixing words which are used lexical and contextual meanings. In 
addition, it was three kinds of translating process: borrowing (25 sentences), literal (14 sentences), and adaptation (28 sentences). From those, the kinds of the translation process in technical devices in a deep structure such as translation, transliteration, transposition, modulation was not found. Finally, code mixing was mostly used as need feeling motive. The frequency using needed feeling motive 23 sentences or utterance with the percentage $35.39 \%$.

Following the conclusion, hopefully, this study can be as a basis for next researchers. In this research, it is focused on the analysis of forms, meaning, and reasons for using Indonesian-English code mixing. In code mixing many interesting things that can be investigated. Therefore, it is recommended to the future researchers to do some research related to this interesting topic in the novel.

\section{REFERENCES}

Alam, S. (2006). Code-mixing in Bangladesh: A case study of non-government white collar service holders and professionals. Bangladesh: Asian Affairs.

As-Safi', A. B. (n.d). Translation process, strategies, and basic theoretical issues. Surabaya: Petra University.

Budianto, L., \& Fardhani, A. E. (2010). A practical guide for translation skill. Malang: UIN Maliki Press.

Chaer, A., \& Agustina, L. (2010). Sociolinguistik perkenalan awal. Jakarta: Rineka Cipta.

Dalimunthe, M. R. (2011). An analysis of code mixing found in girdfield magazine. Unpublished Thesis. Medan: University of Sumatera Utara.

Dika, R. (2011). Manusia setengah salmon. Jakarta: Gagas Media.

Elo, S., \& Kyngas, H. (2007). Jan research methodology the qualitative analysis content process. Journal of Advance Nursing, 62(1), 107.

Gao. (1989). Content analysis: a methodology for structuring and analyzing written material. New York: United State General Accounting Office.

Gunawan, I. (2014). Metode penelitian kualitatif: Teori dan praktik. Jakarta: Bumi Aksara.

Kolosova, A. A. (2011). Intercultural competence or cultural intelligence, Bulgaria: Info Invert.

Mediyanthi, D. (2012). A descriptive of code mixing in social networking (facebook). Unpublished Thesis. Salatiga: State Islamic College of Salatiga.

Moleong, L. J. (2014). Metodologi penelitian kualitatif (edisi revisi). Bandung: PT. Remaja Rosdakarya.

Muhadjir, N. (2000). Metode penelitian kualitatif. Jogyakarta: Rake Sarasin. 
Saputro, A. (2013). The analysis of Indonesian-English code-mixing used in marmut merah jambu novel. Unpublished Thesis. Salatiga: State Islamic College of Salatiga.

Saputro, A. (2013). The analysis of Indonesian-English code-mixing used in marmut merah jambu novel. Unpublished Thesis. Salatiga: State Islamic College of Salatiga.

Saville, M., \& Troike. (2006). Introduction of the second language acquisition. Cambridge: University Press.

Sugiono. (2010). Memahami penelitian kualitatif dilengkapi contoh proposal dan laporan penelitian. Bandung: Alfabeta.

Wardhaugh, R. (2006). An introduction to sociolinguistics (5 ${ }^{\text {th }}$ ed.). Australia: Blackwell.

\section{Author's Brief CV}

Santika Wulandari was graduated from IAIN Palangka Raya, majoring in English Education (S.Pd) in 2015. She has been teaching English at SMA Asseruyaniyyah Seruyan Kalimantan Tengah since 2015. She is interested in the development of ELT and Literature. 
